\title{
ANALISIS PARTISIPASI MASYARAKAT DALAM PENGEMBANGAN OBJEK WISATA DI LAMPUNG SELATAN
}

\author{
Dedy Hermawan, dan Simon S. Hutagalung \\ Jurusan Ilmu Administrasi Negara, Fakultas Ilmu Sosial dan Ilmu Politik Universitas Lampung \\ Email: hermawan.dedy@yahoo.com
}

\begin{abstract}
ABSTRAK. Riset ini memilih fokus pada riset bidang maritim yang di dalam lingkupnya mencakup isu strategis pembangunan industri pariwisata. Adapun tujuan dari riset ini yaitu; (a). melakukan kategorisasi bentuk partisipasi masyarakat yang terjadi dalam aktivitas pengelolaan pariwisata pada daerah pariwisata di Lampung Selatan, (b). menyusun faktor-faktor potensial yang berpotensi mendorong atau menghambat keberhasilan partisipasi masyarakat dalam pengelolaan pariwisata di Lampung Selatan. Oleh karena itu, perlu dihasilkan saran yang terkait dalam bentuk partisipasi pemangku keurgenan khusunya pada hal-hal yang perlu diperkuat dalam rancangan kebijakan. Riset ini mendeskripsikan dan menjelaskan gejala dan kecenderungan pada fokus riset. Bagi fokus pertama dilakukan teknik survei melalui pengumpulan data kunci, sedangkan pada fokus riset kedua dilakukan pengumpulan data melalui observasi, wawancara mendalam dan focus group discussion. Dari hasil riset diketahui jika partisipasi masyarakat yang terderajat dalam dimensi pemikiran, tenaga, dan materi dalam pembangunan destinasi wisata memiliki respon yang berbeda antara partisipasi yang dimobilisasi (diminta partisipasi) dengan partisipasi yang voluntary berdasar inisiatif sendiri. Walaupun demikian masyarakat telah memiliki kesediaan untuk berpartisipasi dalam pembangunan destinasi wisata, hanya saja masih harus dimobilisasi (diminta partisipasi) secara aktif oleh pengelola untuk berpartisipasi.
\end{abstract}

Kata Kunci: Pariwisata; Kolaborasi Stakeholder; Manajemen Pariwisata.

\section{ANALYSIS OF COMMUNITY PARTICIPATION IN DEVELOPMENT OF TOURISM DESTINATION IN SOUTH LAMPUNG}

\begin{abstract}
This research takes the focus of maritime research which includes strategic issues in the development of the tourism industry. The purpose of this research are; (a). categorizing forms of community participation that occur in tourism management activities in the tourism area in South Lampung, (b). formulate potential factors that have the potential to encourage or hinder the success of community participation in tourism management in South Lampung. Thus, recommendations can be generated in the form of things that need to be anticipated or strengthened in the stakeholder participation policy design. This study describes and explains the symptoms and trends that appear in the focus of the study. The survey technique was carried out in the first focus data collection, while in the second research focus the data collection was carried out through observation, in-depth interviews and focus group discussions. From the results of the study, it is known that community participation categorized in the dimensions of thought, energy, and material in the development of tourism objects has a different response between participation that is mobilized (requested participation) with voluntary participation based on their own initiative. Even though the community already has a willingness to participate in the development of attractions, it's just that it still has to be actively mobilized (requested participation) by the manager to participate.
\end{abstract}

Keywords: Tourism, Stakeholder Collaboration, Tourism Management.

\section{PENDAHULUAN}

Sebagai negara berkembang, pembangunan adalah kata kunci untuk semua sektor administrasi negara di Indonesia, termasuk pembangunan pariwisata. Sebagai negara maritim dengan potensi wisata yang besar, negara ini harus mampu melakukan pembangunan di sektor pariwisata. Pembangunan pariwisata pada dasarnya merupakan kegiatan yang mengeksplorasi segala sesuatu dari potensi pariwisata yang berupa bentang alam, produk budaya serta objek kreatif buatan yang semuanya memerlukan sentuhan program yang menyeluruh (Rasoolimanesh et al., 2017). Pembangunan pariwisata yang sukses diderajatkan sebagai pembangunan pariwisata melalui partisipasi dari masyarakat untuk melakukan program secara bersama-sama sehingga pembangunan dapat bermanfaat bagi komunitas manfaat ekonomi, sosial dan budaya di setiap lokasi wisata (Bello et al., 2017). Tujuan dari partisipasi masyarakat dalam pembangunan pariwisata, yaitu, 1) memperkuat keberdayaan masyarakat melalui pembangunan pariwisata, 2) memperkuat peran dan daya partisipasi di dalam masyarakat untuk mendapatkan keuntungan ekonomi, sosial budaya dan pariwisata, 3) memberikan peluang kepada semua kelompok masyarakat, baik oleh jenis kelamin, usia atau latar belakang lainnya untuk menjaga dan melestarikan destinasi wisata. Oleh karena itu, pendekatan terbaik dalam pembangunan pariwisata adalah pendekatan partisipatif(Scheyvens \& Biddulph, 2018).

Program pembangunan partisipatif dapat dikatakan partisipatif ketika mengundang masyarakat untuk menjalankan program. Bahkan, partisipasi ini 
bisa disebut tidak hanya mengundang, tetapi ketika terjadi partisipasi masyarakat dalam perencanaan, pelaksanaan, evaluasi dan pemanfaatan hasil (Daraba, 2017)Desa Tamalate dan Desa Pakkabba sebagai lokasi penelitian. Data diambil dari 55 responden dengan menggunakan kuisioner. Selan-jutnya, data dianalisis dengan menggunakan regresi linear sederhana dengan bantuan program SPSS versi 16,00. Hasil penelitian menjelaskan bahwa program dana desa dilaksanakan berdasarkan Rencana Pembangunan Jangka Menengah (RPJM. Partisipasi dapat mendorong rasa kepemilikan masyarakat, oleh karena itu masyarakat harus selalu dilibatkan dalam pengelolaan areal tempat wisata. Aktivitas partisipasi tersebut seharusnya dimulai dari kegiatan perencanaan, yaitu rencana program yang didiskusikan bersama masyarakat oleh pengelola tempat pariwisata (Begum et al., 2014). Harapannya masyarakat tersebut akan merasa memiliki dan bertanggung jawab terhadap program tersebut, dan turut membantu pencapaiannya (Hermawan \& Hutagalung, 2017). Pada prinsipnya, masyarakat berhak untuk berpartisipasi dalam pengelolaan sektor pariwisata. Hal ni dinyatakan dalam UU Nomor 10 Tahun 2009 Tentang Pariwisata, Pasal 19 ayat 2 yang menyatakan bahwa setiap orang atau orang dalam atau di sekitar obyek wisata memiliki hak prioritas untuk menjadi pekerja atau buruh, penyediaan dan pengelolaan. Dengan adanya payung hukum pariwisata ini maka terdapat landasan yang dapat mengatur hak masyarakat dan bersama-sama mengelola pariwisata.

Keterlibatan masyarakat dalam proses pembangunan sangat mendesak. Menurut Adisasmita (2006) dalam buku pembangunan pedesaan, masyarakat perlu diajak dan dimotivasi untuk berpartisipasi karena sebagai pihak yang mengetahui problem dan keurgenan atau kebutuhan mereka sendiri. Mereka merupakan pelaku yang memahami kondisi lingkungan sosial dan ekonomi masyarakat dimana mereka berada. Disamping itu, terdapat beberapa alasan urgennya partisipasi masyarakat, Pertama adalah fokus utama pembangunan yang menitikberatkan kepada pembangunan kualitas masyarakat dan tujuan akhir dari pembangunan berupa pemberdayaan masyarakat dalam berbagai aspek kehidupan yang ditempuh melalui partisipasi. Memandang masyarakat ebagai subyek dalam pembangunan menjadi sangat urgen dalam rangka memanusiakan masyarakat (Aga et al., 2018). Kedua, partisipasi dapat memunculkan harga diri, rasa memiliki dan harkat dan martabat masyarakat yang meningkat. Ketiga, partispasi dipandang sebagai cermin pelibatan hak-hak individual dalam pembangunan di lokasi tinggal mereka sendiri.
Keempat, partisipasi dapat dikatakan sebagai cara yang efektifmembangun kapasitas masyarakat dalam mengelola aktivitas pembangunan untuk memenuhi kebutuhan keuangan daerah (Tjokrowinoto, 1996). Latar belakang sebab keterlibatan masyarakat dianggap urgen dalam proses pembangunan, menekankan titik bahwa masyarakat sebagai pihak terbaik tahu masalah dan kebutuhan mereka, baik di bidang ekonomi, lingkungan hidup, sosial dan kebijakan, termasuk pembangunan sektor pariwisata (Lestari et al., 2016).

Dalam konteks kebijakan pemerintah, syarat partisipasi sangat bergantung pada kemampuan birokrasi pengelola, jika birokrasi memiliki visi, respon dan antisipasi yang cepat, maka dapat dibentuk pengelolaan industri pariwisata yang mandiri berdasarkan partisipasi masyarakat. Terkait dengan uraian tersebut, riset ini hendak mengkaji dua pertanyaan riset sebagai berikut; (1) apa saja kategorisasi wujud partisipasi masyarakat yang tercipta dalam pengelolaan pariwisata di Lampung Selatan, (2) faktor apa saja yang potensial mendorong ataumenghambatkeberhasilan partisipasimasyarakat dalam pengelolaan pariwisata di Lampung Selatan?

\section{METODE}

Metode riset yang digunakan dalam riset ini berupa survei, riset yang dilakukan untuk mendapatkan informasi atau berita tentang gejala dan bekerja pada fakta-fakta dari lembaga-lembaga sosial, ekonomi, politik atau kelompok atau daerah (Nazir, 1999). Dalam riset ini, survei dilaksanakan pada masyarakat di area destinasi wisata, aparatur pemerintah daerah dan pengusaha di daerah riset. Narasumber dalam riset ini didasarkan pada tujuan riset, sehingga dilakukan pengambilan sampel acak sederhana terhadap informan yang mencakup 10 aparat pemerintah daerah, 10 pengusaha daerah dan 80 masyarakat sekitar daerah tujuan wisata. Berikut sebaran informan di sekitar destinasi wisata utama di Lampung Selatan;

Tabel 1. Sebaran Informan di Sekitar Destinasi wisata Unggulan Lampung Selatan

\begin{tabular}{clc}
\hline No & Nama Destinasi wisata & Jumlah Informan \\
\hline 1 & Pantai Bagoes & 10 \\
2 & Pantai Embe & 10 \\
3 & Pantai Batu Rame & 10 \\
4 & Pantai Guci Batu Kapal & 10 \\
5 & Pantai Canti Indah & 10 \\
6 & Air Terjun Way Kalam & 10 \\
7 & Gunung Rajabasa & 10 \\
8 & Air Terjun Cicurug & 10 \\
\hline & Jumlah & 80 \\
\hline
\end{tabular}


Dalam rangka menganalisis partisipasi masyarakat dan faktor pendorongnya maka digunakan analisis deskriptif, yaitu menganalisis kelompok manusia, obyek, kondisi atau situasi pada aktvitas partisipasi. Dalam riset ini, partisipasi diukur dalam tiga derajat partisipasi, yaitu; pemikiran, tenaga dan materi. Sedangkan teknik analisisnya menggunakan skala likert dengan skor 1-3. Dengan mengkaji faktor internal dan eksternal masyarakat Lampung Selatan, faktor pendorong dan penghambat partisipasi masyarakat dalam pembangunan destinasi wisata hendak dianalisis.

\section{HASIL DAN PEMBAHASAN}

\section{A. Derajatsasi Bentuk Partisipasi Masyarakat dalam Pengelolaan Pariwisata.}

Verhagen (1980) berpendapat bahwa partisipasi adalah bentuk khusus dari kegiatan interaksi dan komunikasi yang terjadi sehubungan dengan Sebaran otoritas, tanggung jawab dan keuntungan. Sementara Theodorson \& Theodorson (1969) mencatat bahwa, dalam pengertian yang umum partisipasi adalah partisipasi atau keterlibatan individual atau masyarakat dalam kegiatan tertentu. Keterlibatan atau keikutsertaan yang tidak pasif, tapi aktif ditunjukkan oleh sikap pihak terkait melalui inisiatif mereka, ide-ide, sikap atau tindakan dari mereka. Jadi sepertinya partisipasi yang lebih tepat jika didefinisikan sebagai yang melibatkan seseorang dalam suatu kelompok sosial untuk berpartisipasi dalam kegiatan masyarakat, bahkan jika itu adalah di luar pengalaman atau profesinya (Oakley \& Programme, 1991).

Oleh karenanya, partisipasi dapat disebut sebagai peran untuk aktif atau untuk tidak aktif dalam aktivitas publik yang dilaksanakan oleh kelompok masyarakat. Dalam simpulannya, partisipasi berarti turut serta atau melibatkan diri dalam aktivitas bersama yang dilaksanakan oleh masyarakat (Murdiyanto, 2011). Derajat partisipasi yang terjadi di dalam masyarakat dapat dianalisis melalui tiga pendekatan, yaitu: (1). Dimensi pemikiran, dideskripsikan sebagai partisipasi dalam wujud pemikiran terkait upaya untuk mengembangkan atraksi di lokasi wisata. Partisipasi ini terlihat dari keluaran pemikiran, baik tentang program paket pembangunan, media yang digunakan dalam pembangunan pariwisata, (2). Dimensi fisik atau tenaga, dideskripsikan sebagai kesediaan terhadap mata pencarian fisik yang dibutuhkan dalam pembangunan objek pariwisata. Partisipasi ini bisa dianalisis dari kesediaan berkontribusi secara fisik dalam persiapan destinasi wisata, sebagai pemandu wisata, atau sebagai penyedia dukungan peralatan infrastruktur kegiatan di destinasi wisata, (3). dimensi materiil, dideskripsikan sebagai sumbangan berwujud materi bagi pembangunan destinasi wisata, termasuk donasi guna pembangunan infrastruktur.

Masyarakat di seputar lokasi wisata menjadi pihak yang lebih memahami kondisi dan kemampuan daerahnya tentu dapat memberikan kontribusi yang sesuai. Masyarakat tersebut yang memiliki pengetahuan serta pengalaman bisa menjadi keunggulan yang berharga dalam mengimplementasikan kegiatan pembangunan. Masyarakat itulah yang paling mengerti masalah yang mereka hadapi dan juga potensi dari wilayahnya dalam menghadapi masalah tersebut (Pakpahan, 2018).

Keterlibatan masyarakat yang terjadi dalam wujud pemikiran, tenaga, dan materi untuk pembangunan destinasi wisata terbentuk secara berbeda pada dua kondisi: (1) Jika masyarakat dimobilisasi (diminta partisipasi) untuk berpartisipasi, dan (2) Jika masyarakat tidak dimobilisasi (tidak diminta partisipasi) dan hanya berdasar kepada inisiatif serta kerelaan mereka (Kusyanto et al., 2019). Riset yang telah dilaksanakan mengidentifikasi kecenderungan perubahan partisipasi dari kondisi partisipasi yang dimobilisasi (diminta partisipasi) menjadi partisipasi yang tanpa dimobilisasi (diminta partisipasi). Diketahui bahwa masyarakat masih enggan untuk berpartisipasi dalam bentuk pemikiran, tenaga dan materi, namun perubahan tersebut masih dalam tingkat sedang. Identifikasi tersebut mengindikasikan jika masyarakat di lokasi wisata sudah memiliki kesediaan untuk partisipatif dalam aktivitas pembangunan destinasi wisata, meskipun masih harus diajak secara aktif untuk berpartisipasi (Viren et al., 2015). Secara lebih rinci kesiapan masyarakat dalam partisipasi akan dijabarkan dalam setiap dimensi partisipasi berikut.

\section{Analisis Partisipasi masyarakat dalam dimensi pemikiran}

Analisis partisipasi masyarakat pada area wisata di Lampung Selatan yang dimobilisasi (diminta partisipasi) untuk berpartisipasi dalam pemikiran terkait inisiatif pembangunan destinasi wisata menunjukkan derajat partisipasi tinggi. Hal ini ditunjukkan bahwa $84.29 \%$ responden berada pada derajat partisipasi yang tinggi, hanya $15.71 \%$ berada pada derajat sedang, serta tidak ditemukan responden dalam derajat rendah. Kondisi berbeda pada responden yang tidak dimobilisasi (tidak diminta) berpartisipasi, hanya $27.14 \%$ responden berada pada kriteria derajat partisipasi tinggi, $72.86 \%$ terderajat sedang, serta tidak ditemukan responden yang terderajat partisipasinya rendah . 
Terjadi kecenderungan perubahan keterlibatan masyarakat dalam dimensi pemikiran dari derajat partisipasi yang dimobilisasi (diminta partisipasi) dengan partisipasi yang tanpa dimobilisasi (diminta partisipasi) sebesar $57.15 \%$, sehingga terjadi perubahan derajat partisipasi dalam derajat sedang sebesar $57.15 \%$. Dapat dipahami jika dalam pemikiran tentang kesadaran masyarakat masih pada taraf menengah untuk berpartisipasi. Diketahui tidak terjadi perubahan bagi derajat partisipasi dalam derajat rendah, artinya masyarakat sudah memiliki kesiapan untuk mengembangkan destinasi wisata, hanya saja pengelola harus lebih aktif mengajak masyarakat untuk berpartisipasi dengan meminta kesediaan mereka menjadi pengelola destinasi wisata dan kesediaan hadir untuk pembahasan program di destinasi wisata.

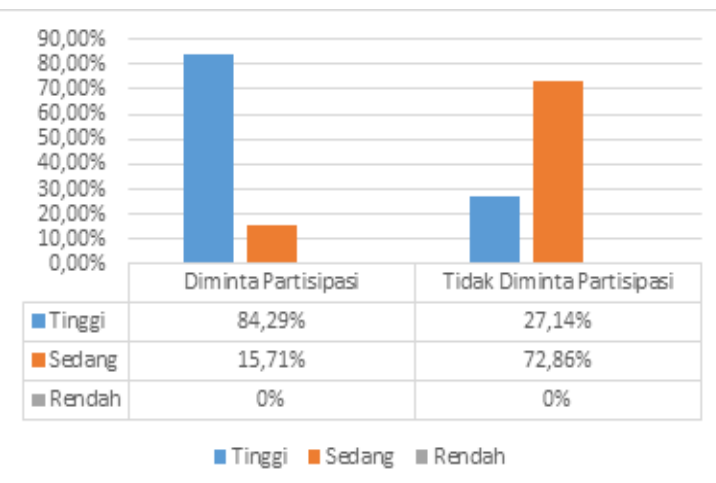

Gambar 1. Sebaran Jenis Partisipasi Pemikiran Masyarakat Dalam Pembangunan Wisata

Terkait dengan kesediaan menjadi pengelola perlu mendapat perhatian, karena $29,03 \%$ responden tidak siap menjadi pengelola meskipun dimobilisasi (diminta partisipasi) menjadi pengelola, sedangkan untuk responden yang tidak dimobilisasi (tidak diminta partisipasi) menjadi pengelola menunjukkan angka yang lebih besar $54,84 \%$. Hal ini berarti bahwa partisipasi masih dalam tahap pemikiran belum secara langsung terlibat sebagai pengelola. Hasil analisis derajat partisipasi masyarakat tentang kemauan masyarakat dalam pembangunan destinasi wisata termasuk tinggi. Hal ini ditunjukkan bahwa 55.71\% responden berada pada derajat yang tinggi dan hanya $44.29 \%$ berada pada derajat sedang, sementara teridentifikasi tidak teridentifikasi responden berada pada derajat rendah. Namun, derajat ini teridentifikasi terkait dengan mereka yang dimobilisasi (diminta partisipasi). Kondisi lain terjadi pada jenis masyarakat yang tidak dimobilisasi (tidak diminta partisipasi), dimana terjadi perubahan derajat partisipasi menjadi $41.43 \%$ responden termasuk derajat partisipasi tinggi, sementara $58.57 \%$ termasuk derajat sedang, sementara tidak teridentifikasi responden yang berada pada derajat partisipasi rendah.
Partisipasi masyarakat dalam bentuk inisiatif terbentuk secara berbeda antara kondisi bila masyarakat dimobilisasi (diminta partisipasi) untuk berpartisipasi dengan derajat jika tidak dimobilisasi (tidak diminta partisipasi). Terjadi kecenderungan perubahan partisipasi dari derajat partisipasi yang dimobilisasi (diminta partisipasi) menjadi derajat partisipasi yang tanpa dimobilisasi (diminta partisipasi). Derajat partisipasi pada derajat tinggi mengalami perubahan sebesar $14.28 \%$, dan beralih ke derajat partisipasi sedang. Kondisi tersebut berarti bahwa partisipasi dalam bentuk inisiatif masyarakat masih ada dalam keadaan situasi sungkan untuk berpartisipasi, namun, perubahan itu masih dalam derajat sedang. Sementara diidentifikasi tidak ada perubahan dalam derajat keterlibatan yang rendah, yang berarti bahwa kelompok masyarakat di lokasi wisata memiliki kemauan untuk berpartisipasi dalam dimensi inisiatif atau kemauan untuk mengembangkan atraksi wisata, tetapi harus didorong secara aktif oleh aktor lain untuk berpartisipasi dalam bentuk ide atau saran terkait dengan atraksi wisata, harga, dan evaluasi kegiatan di area wisata.

Merujuk kepada ketiga hal itu, level kesediaan sebagai pengelola dirasakan perlu diperhatikan karena terdapat $31 \%-41 \%$ responden berada dalam pilihan tidak bersedia memberi sumbangan gagasan atau saran terkait atraksi wisata, harga pelayanan, dan kegiatan di destinasi wisata. Hal tersebut disebabkan karena masyarakat memiliki pandangan apabila segala hal yang berkaitan dengan atraksi wisata di lokasi wisata menjadi kewajiban pengelola destinasi wisata yang mengerti tentang pengelolaan destinasi wisata, harga pelayanan, dan rancangan kegiatan di destinasi wisata. Hal ini bermakna jika inisiatif masyarakat dalam berpartisipasi masih dibatasi pada lingkup adanya inisiatif atau kemauan, namun belum terwujud adanya partisipasi langsung dalam penentuan atraksi wisata, penentuan harga, dan evaluasi terhadap kegiatan di destinasi wisata.

\section{Analisis Partisipasi masyarakat dalam dimensi fisik atau tenaga}

Partisipasi masyarakat dalam dimensi fisik atau kekuasaan dapat digambarkan sebagai partisipasi atau peran dalam bentuk kekuatan fisik yang mungkin dibutuhkan dalam pembangunan tempat wisata, yaitu untuk mempersiapkan lokasi kunjungan, pemandu wisata, penyediaan infrastruktur dan penyediaan peralatan untuk mendukung kegiatan. Hasil analisis partisipasi masyarakat dalam aspek fisik atau tenaga khususnya di bidang penyiapan kunjungan wisata menunjukkan bahwa derajat partisipasi masyarakat yang tinggi. Kondisi itu ditunjukkan $80.00 \%$ 
responden termasuk derajat partisipasi tinggi, $14.29 \%$ berada dalam derajat sedang, serta $5.71 \%$ responden masuk ke dalam derajat rendah. Namun, kondisi tersebut terjadi pada responden yang apabila dimobilisasi (diminta partisipasi), tetapi kondisi terjadi secara berbeda jika tidak dimobilisasi (tidak diminta partisipasi), karena terjadi perubahan kondisi partisipasi yaitu hanya $60.00 \%$ responden terderajat partisipasi tinggi, sementara $34.29 \%$ termasuk derajat sedang, serta $5.71 \%$ responden berada dalam derajat partisipasi rendah.

Partisipasi masyarakat dalam dimensi fisik atau tenaga untuk mempersiapkan sarana prasarana dan peralatan di zone wisata teridentifikasi memiliki hasil yang berbeda antara kondisi masyarakat dimobilisasi (dimintapartisipasi)dengankondisi tidak dimobilisasi (tidak diminta partisipasi). Terjadi kecenderungan perubahan ketegori partisipasi dari partisipasi yang dimobilisasi (diminta partisipasi) menjadi partisipasi yang tanpa dimobilisasi (tidak diminta partisipasi). Derajat partisipasi yang tinggi mengalami perubahan sebesar $65.71 \%$, dan beralih ke derajat partisipasi sedang. Kondisi tersebut bermakna bahwa dalam derajat partisipasi fisik atau tenaga yang berbentuk sarana prasarana dan peralatan di lokasi wisata masih belum memiliki kesediaan penuh untuk dipilih masyarakat, namun perubahan tersebut masih dalam tingkat yang sedang. Tidak diidentifikasi perubahan pada derajat partisipasi rendah, yang berarti bahwa orang-orang sendiri mempunyai kesiapan untuk berpartisipasi dalam mempersiapkan fasilitas dan peralatan kerja di wilayah destinasi wisata, hanya perlu didorong secara aktif oleh pihak pengelola untuk berpartisipasi.

Aspek ini perlu menjadi perhatian dikarenakan teridentifikasi $25,61 \%$ responden yang tidak bersedia untuk menyediakan dan menjaga sarana prasarana serta peralatan yang hendak digunakan di lokasi wisata. Masyarakat memiliki pandangan bahwa masalah yang berkaitan dengan alat-alat yang digunakan untuk kegiatan di lokasi wisata adalah tugas dan kewajiban pihak pengelola yang harus menyediakannya. Ini juga berarti bahwa partisipasi masyarakat dalam fisik atau tenaga dalam kegiatan penyediaan dan pemeliharaan infrastruktur masih terbatas dalam kesediaan untuk menjaga kebersihan dan tidak berkitan dengan fasilitas, prasarana dan peralatan yang digunakan dalam kegiatan di destinasi wisata.

Sedangkan hasil analisis tingkat keterlibatan masyarakat dalam dimensi fisik atau tenaga pada saat atraksi wisata dilaksanakan menunjukkan derajat partisipasi masyarakat termasuk sedang. Hal ini ditunjukkan oleh derajat partisipasi 35,71\% responden diderajatkan partisipasi yang tinggi, sementara $32,86 \%$, yang termasuk sedang dan $31,43 \%$ responden yang memiliki keterlibatan yang rendah. Namun, derajat ini terjadi pada responden dimobilisasi (partisipasi diminta). Kondisi yang berbeda dari responden dalam derajat tidak dimobilisasi (partisipasi yang tidak diminta), dimana hanya $15,71 \%$ responden termasuk partisipasi tinggi, $15,71 \%$, yang termasuk sedang, dan $68,57 \%$ dari responden berada pada derajat keterlibatan yang rendah.

Partisipasi masyarakat dalam aspek kerja selama pelaksanaan kegiatan di tempat yang berbeda terjadi ketika orang dimobilisasi (partisipasi diminta) untuk berpartisipasi jika tidak dimobilisasi (partisipasi yang tidak diminta). Kecenderungan terjadi penyusutan partisipasi responden dimobilisasi (partisipasi diminta) menjadi yang tanpa dimobilisasi (partisipasi tidak diminta), derajat partisipasi derajat tinggi menurun sebesar $20 \%$, partisipasi derajat sedang adalah $17,15 \%$, sementara pada derajat keterlibatan yang rendah telah meningkat jadi $37,14 \%$. Ini berarti bahwa orang-orang masih enggan untuk berpartisipasi dalam bentuk kontribusi tenaga atau fisik. Perubahan utama yang terkandung dalam derajat keterlibatan yang rendah, yaitu orang yang tidak memiliki kekuatan dalam bentuk kesediaan untuk berpartisipasi dalam melaksanakan kegiatan untuk membangun destinasi wisata. Masyarakat lebih memilih untuk mempercayakan pengelolaan dan pelaksanaan kegiatan kepada kaum muda sebagai pemandu wisata dalam kegiatan destinasi wisata. Adapun derajat partisipasi tersebut dapat diamati dari gambar berikut:

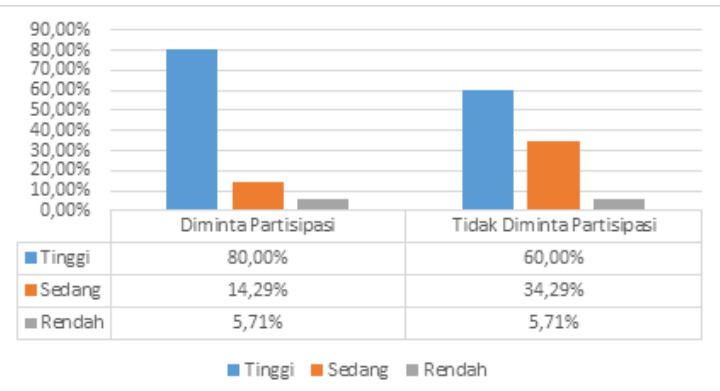

Gambar 2. Sebaran Derajat Partisipasi Tenaga Masyarakat Dalam Pembangunan Wisata di Lampung Selatan

Berdasarkan uraian sebelumnya, partisipasi tenaga yang signifikan dalam pelaksanaan kegiatan membutuhkan perhatian, karena ada 35\% -77\% dari responden tidak bersedia untuk menjadi pemandu dalam melakukan kegiatan di destinasi wisata. Hal ini karena mereka percaya bahwa segala sesuatu terkait kegiatan di destinasi wisata, terutama sebagai pemandu wisata, merupakan wewenang penuh pihak pengelola yang memahami keseluruhan kebutuhan 
dan kriterianya, namun melihat sebagian besar pengunjung lebih dari 30 tahun, maka dibutuhkan anak-anak muda untuk berpartisipasi dalam pelatihan atau pendidikan sebagai calon pemandu wisata.

\section{Derajat partisipasi masyarakat dalam dimensi materiil}

Partisipasi masyarakat pada dimensi ini adalah segala bentuk sumbangan barang dan uang yang diberikan dalam konteks pembangunan pariwisata. Partisipasi ini merupakan partisipasi yang memiliki nilai finansial, jenis partisipasi ini memberikan kontribusi yang sama besarnya dengan bentuk lain dari partisipasi.

Hasil analisa partisipasi masyarakat dalam bentuk materiil untuk aktivitas pembangunan pariwisata diketahui berada pada derajat partisipasi masyarakat rendah. Berada di angka partisipasi hanya $31,43 \%$ responden yang diklasifikasikan sebagai partisipasi tinggi, sementara derajat sedang sebesar $30,00 \%$, dan $38,57 \%$ responden yang terderajat keterlibatan yang rendah. Namun, derajat ini terjadi pada responden yang dimobilisasi (diminta partisipasi). Kondisi yang berbeda pada responden yang tidak dimobilisasi partisipasi (partisipasi yang tidak diminta) hanya 24,29 responden termasuk derajat keterlibatan tinggi, $28,57 \%$ termasuk derajat sedang, dan sebanyak $47,14 \%$ responden yang terderajat partisipasi rendah. Sebaran persentase tersebut dapat diamati dari gambar berikut:

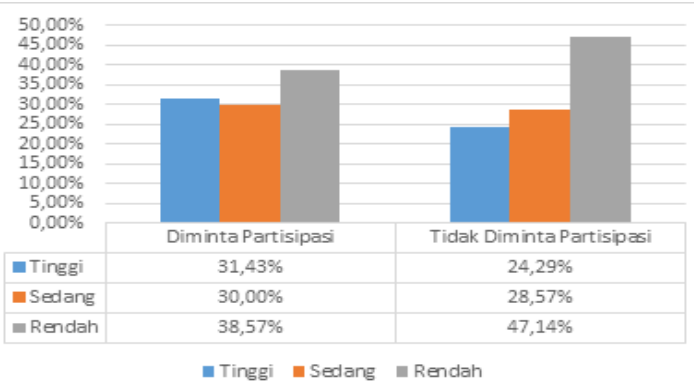

Gambar 3. Sebaran Derajat partisipasi Materiil Masyarakat Dalam Pembangunan Wisata di Lampung Selatan

Partisipasi masyarakat dalam dimensi materiil pada pelaksanaan kegiatan di lokasi wisata terjadi dalam wujud berbeda antara saat masyarakat dimobilisasi untuk berpartisipasi (partisipasi diminta) dengan saat mereka tidak dimobilisasi (partisipasi yang tidak diminta). Ada kecenderungan perubahan tingkat keterlibatan orang-orang yang dimobilisasi (partisipasi diminta) dengan mereka yang belum dimobilisasi (partisipasi diminta). Derajat partisipasi derajat tinggi berubah menjadi $2,86 \%$, sementara derajat partisipasi sedang sebesar 4,28\%, sedangkan derajat keterlibatan yang rendah meningkat 7,14\%. Kondisi itu bermakna bahwa dalam dimensi materiil, masyarakat masih pada kondisi enggan untuk berpartisipasi. Kondisi ini terkait dengan keadaan ekonomi masyarakat di kawasan wisata Lampung Selatan masih relatif belum seluruhnya sejahtera. Kelompok masyarakat lebih memilih untuk mempercayakan hal tersebut kepada pengelola dan pemerintah daerah guna menyediakan sumber daya materiil.

\section{B. Faktor penghambat atau pendorong partisipasi masyarakat dalam pengelolaan pariwisata.}

Faktor pendukung partisipasi masyarakat dalam pengelolaan pariwisata untuk berpartisipasi dalam pembangunan destinasi wisata dalam segala bentuk merupakan porsi yang urgen dari kesadaran yang dimiliki oleh masyarakat (Dewi \& Hermawan, 2018). Menurut Kuntjoro-Jakti (1994), bahwa faktor utama yang mendorong partisipasi masyarakat dalam pelaksanaan pembangunan, yaitu (1) Inisiatif atau kemauan; (2) Kapasitas atau kemampuan; dan (3) Kesempatan untuk berpartisipasi. Kesadaran atau kemauan dari masing-masing pribadi untuk ikut serta dalam aktivitas pembangunan, karena hadirnya kepedulian, kesadaran dan keinginan masyarakat untuk terlibat secara langsung maupun tidak langsung dalam pembangunan tersebut.

Berdasarkan data yang telah dianalisis diketahui bahwa keterlibatan masyarakat memberikan kontribusi dalam wujud materi yang didasarkan atas kesadaran/ kemauan dari masyarakat tersebut. Masyarakat masih mengandalkan bantuan dari pemerintah daerah, namun Pemerintah Kabupaten Lampung Selatan juga merasakan terbantu atas bantuan materiil yang diberikan oleh perusahaanperusahaan yang dikordinasikan oleh Kabupaten Lampung Selatan dalam bentuk tanggung jawab sosial perusahaan (CSR). Meskipun kesadaran/ kemauan masyarakat untuk terlibat secara materi belum terlihat, namun masih adanya inisiatif dukungan masyarakat dalam bentuk pemikiran bagi pembangunan destinasi wisata di Pemerintah daerah Lampung Selatan. Hal ini dibuktikan dengan adanya rencana kontribusi masyarakat yang terungkap dalam musyawarah masyarakat dan partisipasi masyarakat, masyarakat tersebut ikut serta dalam rencana tersebut dan mengusulkan kepada pemerintah daerah untuk membangun beberapa fasilitas umum, seperti safety station atau pemandian umum.

Seperti yang diungkapkan para ahli oleh Cohen \& Uphoff (1980), inisiatif untuk berpartisipasi dapat berasal dari masyarakat itu sendiri dan tidak hanya pemerintah (top down), di mana bentuknya dalam bentuk pembangunan yang otonom sebagai titik awal untuk partisipasi publik. Oleh karena itu, 
kehadiran inisiatif publik merupakan kontribusi urgen yang muncul untuk menunjukkan apabila masyarakat memiliki perhatian besar untuk terus mendukung pembangunan destinasi wisata yang dapat bermanfaat bagi masyarakat di Kabupaten Lampung Selatan.

Sementara itu, menurut Plummer (2013) ada beberapa faktor yang mempengaruhi derajat partisipasi masyarakat dalam proses partisipasi, yaitu: (a) wawasan dan keahlian, (b) mata pencarian, (c) tingkat pendidikan, (d) jenis kelamin, (e) kepercayaan atau budaya, dan ( f) Faktor-faktor eksternal. Hasil analisis dari keenam faktor tersebut dalam lingkup pembangunan destinasi wisata di Lampung Selatan; dapat diketahui: (1) pengetahuan dan pemahaman masyarakat teridentifikasi masih rendah. Ketersediaan berbagai atraksi wisata diharapkan memberikan dampak kesejahteraan masyarakat untuk meningkatkan kualitas hidup di wilayah Lampung Selatan, namun ternyata masih belum dipahami oleh orang-orang pada umumnya disebabkan ketidaktahuan dan kurangnya pemahaman masyarakat, sehingga partisipasi masyarakat rendah. (2) mata pencarian masyarakat, diidentifikasi jika latar mata pencarian kelompok masyarakat bisa menjadi salah satu faktor penghambat partisipasi. Kebanyakan mereka memiliki latar belakang sebagai buruh, petani, pekerja konstruksi, PNS dan wiraswasta. Latar mata pencarian merupakan faktor penghambat bagi perubahan derajat partisipasi masyarakat karena orang tidak memiliki waktu untuk berpartisipasi. Namun, sebagian kecil responden mengutarakan bahwa tidak peduli seberapa sibuk mata pencarian dan sedikit waktu luang, jika memiliki keinginan untuk berpartisipasi tetap akan ikut serta, meskipun bentuk dan waktunya berbeda. Bagi yang memiliki kesibukan waktu untuk terlibat secara aktif dalam pemikiran dan tenaga sebenarnya bisa terlibat dalam bentuk materi, hanya saja terbentur masalah perekonomian. (3) tingkat pendidikan masyarakat, latar belakang tingkat pendidikan yang rendah dan masih banyak masyarakat yang buta huruf adalah salah satu faktor penghambat masyarakat untuk berpartisipasi dalam program pariwisata. Dari hasil riset teridentifikasi apabila latar belakang pendidikan berkontibusi sebagai faktor penghambat bagi masyarakat untuk berpartisipasi mengingat sebagian besar pendidikan terakhir masyarakat maksimal adalah SMA dan mayoritas SMP dan SD, hal ini dapat diketahui dalam data pendidikan terakhir masyarakat. Pendidikan memang sudah dikenali sebagai salah satu faktor utama yang menentukan derajat partisipasi (Marginson, 2016)leading towards high participation systems (HPS. (4) jenis kelamin, faktor ini merupakan salah satu penghambat juga dalam mewujudkan partisipasi masyarakat di lokasi wisata. Jumlah masyarakat berjenis kelamin laki-laki lebih lebih sedikit daripada jumlah masyarakat yang berjenis kelamin perempuan. Meski demikian, dapat diidentifikasi apabila jenis kelamin bukan merupakan faktor yang mutlak untuk mengukur keikutsertaan masyarakat dalam partisipasi walau ada beberapa jenis aktivitas wisata yang hanya bisa dilakukan oleh pria, antara lain pemandu wisata adventure yang berisiko tinggi dan membutuhkan keberanian. Secara menyeluruh jenis kelamin bukanlah merupakan faktor utama penghambat partisipasi masyarakat.

(5) heterogenitas masyarakat, dalam hal ini bentuk identitas sosial budaya dapat menjadi hambatan, karena masyarakat yang sangat heterogen akan membutuhkan solidaritas sosial yang tinggi untuk mendorong partisipasi masyarakat. Orang Lampung Selatan dikenal sangat bangga dengan budayanya, Lampung Selatan dikenal memiliki beragam suku dengan budaya mereka sendiri, yaitu Lampung, Banten, Jawa dan lain-lain. Aspek budaya yang berkembang di masyarakat beragam, termasuk beberapa keyakinan yang kadang bertentangan dengan keyakinan pihak lainnya. Saat ini terdapat beberapa orang enggan untuk berpartisipasi dalam kegiatan karena keyakinan atau budayanya. Dari analisis data riset teridentifikasi jika kepercayaan yang timbul dari budaya heterogen dapat jadi faktor penghambat derajat partisipasi masyarakat, meskipun sifatnya personal. Pada awalnya, ada satu atau dua orang dan komunitas yang bertentangan dalam beberapa aspek, tetapi pada akhirnya masyarakat bisa bertoleransi satu sama lain.

(6) faktor eksternal, faktor-faktor eksternal ini termasuk semua kelompok yang berkeurgenan, dan berdampak pada perkembangan pariwisata di kawasan Lampung Selatan. Tokoh kuncinya adalah Pemerintah Kabupaten Lampung Selatan yang sangat berpengaruh, termasuk Bappeda dan Dinas Pariwisata dan Ekonomi Kreatif Lampung Selatan, yang berperan urgen dalam pembangunan pariwisata di Lampung Selatan. Melalui riset ini dapat diidentifikasi bahwa faktor eksternal tersebut merupakan faktor pendukung. Menurut Dinas Pariwisata dan Ekonomi Kreatif Lampung Selatan, kebijakan dan rencana pariwisata yang tidak melibatkan masyarakat akibat perencanaan yang tidak optimal menjadi kendala karena rencana yang dilaksanakan belakangan seringkali membosankan, membuat masyarakat jenuh, dan keterbatasan dana untuk kegiatan.

Upaya dipimpin pemangku keurgenan untuk meningkatkan partisipasi masyarakat dalam 
pembangunan potensi destinasi wisata teridentifikasi sudah cukup banyak, antara lain, mempromosikan pembentukan wadah bagi masyarakat untuk menggali potensi wisata dengan mengundang mereka untuk bergabung dengan organisasi sadar wisata. Hasil analisis data menunjukkan bahwa Bappeda dan Dinas Pariwisata dan Ekonomi Kreatif Lampung Selatan telah melaksanakan upaya untuk memperkuat partisipasi masyarakat, seperti mengundang orang untuk menjadi anggota Pokdarwis, kerjasama dan kemitraan dengan sektor swasta, menarik orang untuk berpartisipasi melalui pelatihan termasuk pelatihan yang diberikan oleh Dinas Pariwisata dan Ekonomi Kreatif Lampung Selatan, bisa juga usaha lain seperti penguatan kemampuan kelompok pemuda untuk membentuk event organizer sehingga memiliki pendapatan yang cukup jika mereka aktif berpartisipasi. Media juga membantu dengan website dan blog tentang destinasi wisata di wilayah Lampung Selatan, semua hal itu adalah faktor yang memberikan kontribusi untuk pembangunan program pariwisata.

\section{SIMPULAN}

Partisipasi masyarakat dalam dimensi pemikiran, tenaga dan materi untuk pembangunan pariwisata terwujud secara berbeda dalam kondisi apabila masyarakat dimobilisasi (partisipasi diminta) untuk berpartisipasi dalam mobilisasi (partisipasi yang tidak diminta). Sebuah kecenderungan perubahan terjadi pada derajat telah dimobilisasi (partisipasi diminta) menjadi partisipasi tidak dimobilisasi (partisipasi diminta). Ini mungkin berarti bahwa masyarakat masih belum maksimal termotivasi untuk terlibat dalam bentuk pemikiran, tenaga dan materiil, tetapi perubahan ini masih dalam derajat sedang. Tidak ada perubahan dalam derajat derajat keterlibatan yang rendah, yang berarti mereka memiliki kemauan untuk berpartisipasi dalam pembangunan tempat wisata, hanya saja mereka harus aktif didorong oleh aktor lainnya untuk berpartisipasi.

Faktor pendukung partisipasi masyarakat dalam pengelolaan pariwisata adalah kesadaran masyarakat untuk berperan serta dalam pembangunan destinasi pariwisata, baik itu ide / pemikiran, uang, materi / komoditas maupun tenaga, meskipun harus melalui undangan dulu dari pemerintah daerah.

Faktor-faktor yang menghambat partisipasi Kota Lampung Selatandalampengelolaanpariwisataantara lain: (1). Pengetahuan dan pemahaman masyarakat tentang pengelolaan pariwisata masih sangat rendah, (2). Mata pencarian masyarakat berubah seiring dengan beban kerja, sehingga masyarakat beranggapan bahwa kecil kemungkinannya untuk berperan aktif (3). Rendahnya tingkat pendidikan masyarakat merupakan faktor yang menghambat keinginan dan kapasitas masyarakat untuk berpartisipasi dan melaksanakan rencana tersebut, (3). Rendahnya tingkat pendidikan masyarakat merupakan faktor yang menghambat keinginan dan kapasitas masyarakat untuk berpartisipasi dan melaksanakan rencana, (4). Heterogenitas komunitas dalam bentuk kepercayaan (trust) dengan latar belakang ras, etnis, dan budaya tertentu menjadi faktor penghambat, karena orang dengan heterogenitas tinggi membutuhkan solidaritas sosial yang lebih tinggi untuk menghasilkan partisipasi komunitas yang kolaboratif (5). Faktor eksternal (pemangku keurgenan yang berwenang), yaitu kebijakan dan inisiatif yang relevan serta berdampak pada perkembangan wisata Lampung Selatan.

\section{UCAPAN TERIMA KASIH}

Penulis berterima kasih kepada Kementerian Ristekdikti/Kemendikbud atas pembiayaan riset ini melalui skim Riset Unggulan Terapan Perguruan Tinggi Tahun 2019-2020, Ketua LPPM Universitas Lampung dan seluruh pihak terkait dalam riset ini.

\section{DAFTAR PUSTAKA}

Adisasmita, R. (2006). Pembangunan Pedesaan dan Perkotaan. Yogyakarta. Graha Ilmu.

Aga, D.A., Noorderhaven, N. \& Vallejo, B. (2018). Project beneficiary participation and behavioural intentions promoting project sustainability: The mediating role of psychological ownership. Development Policy Review, 36, (5), 527-546. https://doi. org/10.1111/dpr.12241

Begum, H., Er, A.C., Alam, A.S.A.F. \& Sahazali, N. (2014). Tourist's Perceptions towards the Role of Stakeholders in Sustainable Tourism. Procedia - Social and Behavioral Sciences, 144, 313-321. https://doi.org/10.1016/j. sbspro.2014.07.301

Bello, F.G., Lovelock, B. \& Carr, N. (2017). Constraints of community participation in protected area-based tourism planning: The case of Malawi. Journal of Ecotourism, 16, (2), 131-151. https://doi.org/10.1080/147240 49.2016.1251444

Cohen, J.M., \& Uphoff, N. T. (1980). Participation's place in rural development: Seeking clarity 
through specificity. World Development, 8, (3), 213-235. https://doi.org/10.1016/0305750X(80)90011-X

Daraba, D. (2017). Pengaruh Program Dana Desa Terhadap Derajat Partisipasi Masyarakat Di Kecamatan Galesong Utara Kabupaten Takalar. Sosiohumaniora, 19, (1), 52-58. https://doi. org/10.24198/sosiohumaniora.v19i1.11524

Dewi, W. K., \& Hermawan, D. (2018). Partisipasi Civil Society Dalam Mengembangkan Pariwisata Di Kabupten Lampung Selatan (Studi Pada Kelompok Sadar Wisata Di Kabupaten Lampung Selatan). Administratio: Jurnal Ilmiah Administrasi Publik Dan Pembangunan, 8, (2).

Hermawan, D. \& Hutagalung, S.S. (2017). Membangun Partisipasi Publik Berbasis Perilaku: Studi Kasus di Provinsi Lampung. in Transformasi Sosial Menuju Masyarakat Informasi Yang Beretika dan Demokratis (pp. 35-54). Universitas Terbuka.

Kuntjoro-J.D. (1994). Perangkap Pengderajatan Abstrak" atau Persoalan yang Dihadapi dalam Memecahkan Masalah Keterbelakangan Dalam Dorodjatun Kuntjorojakti. Kemiskinan Di Indonesia.

Kusyanto, M., Triyadi, S. \& Wonorahardjo, S. (2019). Characterization Of The Community Participation Model In The Mosque ConstructionProcess(Case Study: Construction Of Mosques In Demak Regency). Journal of Islamic Architecture, 5, (3), 159-165. https:// doi.org/10.18860/jia.v5i3.5791

Lestari, G., Armawi, A. \& Muhamad, M. (2016). Partisipasi Pemuda Dalam Mengembangkan Pariwisata Berbasis Masyarakat Untuk Meningkatkan Ketahanan Sosial Budaya Wilayah (Studi di Desa Wisata Urgensari, Umbulharjo, Cangkringan, Sleman, D.I. Yogyakarta). Jurnal Ketahanan Nasional, 22, (2), 137-157. https://doi.org/10.22146/ jkn. 17302

Marginson, S. (2016). The worldwide trend to high participation higher education: Dynamics of social stratification $\mathrm{n}$ nclusive systems. Higher Education, 72, (4), 413-434. https:// doi.org/10.1007/s10734-016-0016-x
Murdiyanto, E. (2011). Partisipasi Masyarakat Dalam Pembangunan Desa Wisata Karanggeneng, Purwobinangun, Pakem, Sleman. 11.

Nazir, M. (1999). Metode riset sosial. Jakarta: PT Bina Aksara.

Oakley, P. \& Programme, W.E. (1991). Projects with People: The Practice of Participation in Rural Development. International Labour Organization.

Pakpahan, R.V.(2018). Partisipasi Masyarakat Dalam Pengawasan Pengelolaan Dana Desa (DD) di Desa Parlombuan Kecamatan Pangaribuan Kabupaten Tapanuli Utara. http://repositori. usu.ac.id/handle/123456789/7598

Plummer, J. (2013). Municipalities and Community Participation: A Sourcebook for Capacity Building. Routledge. https://doi. org/10.4324/9781315071794

Rasoolimanesh, S.M., Jaafar, M., Ahmad, A.G. \& Barghi, R. (2017). Community participation in World Heritage Site conservation and tourism development. Tourism Management, 58, 142-153. https://doi.org/10.1016/j. tourman.2016.10.016

Scheyvens, R., \& Biddulph, R. (2018). Inclusive tourism development. Tourism Geographies, 20, (4), 589-609. https://doi.org/10.1080/146 16688.2017.1381985

Theodorson, G.A., \& Theodorson, A.G. (1969). A Modern Dictionary of Sociology. Eweb: 1917. https://repository.library.georgetown. edu/handle/10822/762995

Tjokrowinoto, M. (1996). Pembangunan: Dilema dan tantangan. Pustaka Pelajar.

Verhagen, K. (1980). Changes in Tanzanian Rural Development Policy 1975-1978. Development and Change, 11, (2), 285-295. https://doi.org/10.1111/j.1467-7660.1980. tb00070.x

Viren, P. P., Vogt, C. A., Kline, C., Rummel, A. M., \& Tsao, J. (2015). Social network participation and coverage by tourism industry sector. Journal of Destination Marketing \& Management, 4, (2), 110-119. https://doi. org/10.1016/j.jdmm.2015.03.004 